\title{
A Natureza, o Capital e o Trabalho: Educação Ambiental e crítica social
}

\author{
José Geraldo Pedrosa ${ }^{1}$
}

Resumo: $O$ artigo busca estabelecer elos entre três conceitos importantes para o entendimento do télos da educação no capitalismo tardio: a natureza, o indivíduo humano e a sociedade. A referência básica para a análise são idéias de autores da Escola de Frankfurt: Adorno, Horkheimer e Marcuse. O artigo foi escrito a partir da lógica das contraposições, explorando a interlocução dos frankfurtianos com autores de diferentes épocas, tanto modernos quanto pré-modernos. A idéia é demonstrar como, desde os primórdios, a dominação tem marcado a relação entre a natureza, a cultura e o indivíduo. O texto caracteriza o homem como ser naturalhistórico para afirmar que a dominação da natureza é autodominação. Ao final, aborda-se a questão da revolta da natureza: não no sentido de uma revolta da natureza contra o homem, como se o homem não fosse ele próprio um ser natural, mas revolta de uma natureza reprimida por uma sociedade que só exige renúncia e sacrifício. É nesse ponto que se estabelecem pistas para o entendimento do télos da educação: acirrar as contradições entre o indivíduo e a totalidade funcional e manter acesas as possibilidades de resistência e de rebelião.

Palavras-chave: Natureza, Capitalismo, Educação Ambiental.

Abstract: This article aims at establishing links among three important concepts to the understanding of the télos of education in late capitalism: nature, human individual and society. The basic references for the analysis are ideas of authors from the Frankfurt school: Adorno, Horkheimer and Marcuse. The article was written from the contradistinction logic, exploring the dialogue between Frankfurt thinkers and authors from different times, modern and premodern ones. The idea is to demonstrate how, since the primordium of times, domination has shaped the relation among nature, culture and individual. The text characterizes man as a natural-historical being, to affirm that to dominate nature is self-domination. At the end, the revolt of nature is discussed: not as a revolt of nature against man, as if man were not a natural being, but as a revolt of a nature that was suppressed by a society that only demands renunciation and sacrifice. It is at this point that clues which help to understand the télos of education are established: to increase the contradictions between individual and functional totality and to keep the possibilities of resistance and rebellion alive.

Keywords: Nature, Capitalism, Environmental Education.

1 Professor Adjunto do Depto. de Educação do Centro Federal de Educação Tecnológica de Minas Gerais. Contato: R. Salinas, 206, apart. 904 - V.Cruzeiro, Divinópolis - MG CEP 35500-020.E-mail: jgpedrosa@uol.com.br ou jgpedrosa@dppg.cefetmg.br . 


\section{Introdução}

Com a divulgação cada vez mais constante de notícias sobre a condição atual da vida na Terra e com a ampla e instantânea difusão na rede mundial de computadores de prováveis cenários futuros notadamente aqueles referentes à elevação do calor, à falta de água e à degradação do ar -, uma estranha sensação começa a incomodar. Aos poucos, a humanidade vai sendo informada sobre alguns acontecimentos mais alarmantes que colocam em risco a vida ou, em melhor hipótese, vão impor renúncias, sacrifícios e penúrias cada vez mais intensos. É a estranha sensação de beco sem saída. A sensibilidade pragmática, mais uma vez, indagará: que fazer? A pergunta pode ser tardia, mas, como na psicanálise, a diagnose pode ser a terapia. Adorno (1995) chama isso de auto-reflexão. Há, pois, que se persistir na crítica: é ela que pode revitalizar a esperança e tornar possível a fuga do "círculo que torna a fuga impossível" (HORKHEIMER, 2000). Mas quais seriam as referências para um olhar crítico do tempo presente? Quais seriam as referências para uma crítica alargada, capaz de compreender não apenas as relações entre os homens mas as relações da Cultura com a Natureza? Como fazer a crítica para além dos parâmetros antropocêntricos? A hipótese aqui adotada é que há duas referências inevitáveis para a crítica do tempo presente: o Capital e a Natureza. A idéia de Natureza é a referência que permite pensar o quanto é estreito o entendimento do Homem na condição de único sujeito. Permite também pensar que o Homem não pode ser entendido a partir da relação entre ele e suas coisas. É uma idéia que remete o pensamento ao mais remoto dos preconceitos ou a esse preconceito-modelo que é o antropocentrismo, isso que faz do Homem um ser narcíseo desde o princípio. Ao mesmo tempo, é impossível definir o mundo contemporâneo sem a palavra-chave Capitalismo. O conceito de Capital é que evidencia o que é um traço marcante da vida contemporânea: a mercantilização, isso que permite pensar no quanto o homem já não é mais a medida de todas as coisas.

Este artigo é destinado aos ambientalistas e, mais ainda, àqueles que de algum modo estão envolvidos com a assim chamada Educação Ambiental. Também é dedicado à interlocução com aqueles que insistem 
em afirmar que Karl Marx e suas teses sobre o sistema produtor de mercadorias estão superados e não fornecem mais inspiração para a compreensão da vida contemporânea. $\mathrm{O}$ argumento básico é que o ambientalismo perde ao descartar Marx, assim como se descartam os valores de troca na era da substitubilidade. Mais do que isso, Marx é um humanista antiantropocêntrico. É humanista no sentido de que historiciza a existência humana: seu problema é a autogeração do homem enquanto processo. É antiantropocêntrico na medida em que entende o homem como um ser de relações e, portanto, de alteridade. Em Marx (1987), a primeira alteridade humana é a natureza, sem a qual não há humanidade. É esse entendimento da naturalidade histórica do homem que se relaciona ao entendimento do capitalismo para além da tragédia econômica: como tragédia humana. Algo que também se quer demonstrar é que a Natureza é uma idéia importante para a compreensão da vida no capitalismo tardio. No século XX, a remota obsessão de dominar a Natureza transformou-se em ideologia e fez expandir uma antinomia entre o natural e o cultural. Ao se esforçar para dominar a Natureza o homem reduz-se a trabalhador, sua vida torna-se prejudicada e sua própria natureza é recalcada. É dessa repressão que emerge a revolta da Natureza, expressa de variados modos de adoecimento, de agressividade ou de indiferença.

\section{A natureza da crítica à vida no Capitalismo tardio}

Há que se clarear desde já o sentido dessa crítica. Os críticos sempre experimentaram o relativo isolamento: "O significado histórico do seu trabalho não se estabelece por si mesmo...” (HORKHEIMER, 2000, p. 139). Assim foi na Antigüidade, na Idade Média e na Modernidade: mercantil ou estatal, ocidental ou oriental. $\mathrm{Na}$ contemporaneidade conformista e ainda deslumbrada com a técnica, uma das caricaturas dos críticos $^{2}$ coloca-os como utopistas: como se ainda fizesse sentido lidar com utopias em tempos de neobarbarismo. Mas se ainda é permitido imaginar um futuro de paz, ele já não é mais utopia, mas possibilidade histórica. Por isso, identificar apressadamente crítica com utopia é fertilizar o campo da

\footnotetext{
${ }^{2}$ Essa caricatura é difusa: está em textos científicos, na mídia e no senso comum.
} 
estereotipagem: é desqualificação tanto da crítica quanto da utopia. É a compreensão profunda do tempo presente que proporciona uma imagem de futuro. É a partir das contradições, das irracionalidades e também das possibilidades históricas que são desperdiçadas no presente que ainda se pode pensar num estado racional da existência humana. Não há, pois, um projeto inegociável de sociedade. A rigor, não há projeto: há possibilidades inscritas nas contradições históricas.

Mas há também a negação dos críticos oriunda do antropocentrismo culturalista que supõe, ao contrário do militantismo marxista do século XX, que a cena contemporânea é marcada por um descolamento entre cultura e economia. Se o século XX reduziu a cultura ao campo da supra-estrutura, o culturalismo pós-modernista eleva a cultura ao campo dos fenômenos flutuantes, capaz de operar por si só. Nas palavras de Bhabha (2001), a idéia é clara: de um lado economia e sociedade e de outro a pluralidade de identidades que se formam a partir de si próprias, incondicionadas. Aí, a caricatura coloca os críticos como economicistas. Puro estigma: a economia, causa da miséria humana, é o foco inicial da crítica. Ademais, no capitalismo tardio (ADORNO, 1994), o que ocorre não é a separação entre mercado e cultura, mas a transformação do econômico em cultural e do cultural em econômico. Não se trata mais de duas esferas: a síntese é hollywoodiana. Na cena contemporânea, "a televisão e o cinema norte-americanos enquadram-se (...) tanto na base quanto na superestrutura; são tão econômicos quanto culturais e são, junto com o setor agrícola e o de armamentos, os principais bens de exportação dos Estados Unidos...” (JAMESON, 2001, p. 18).

Hobsbawm (1995) destacou a brevidade do século XX: se foi breve, é porque foi intenso e tenso. Há um conjunto de acontecimentos na cena contemporânea que desafiam a atualidade do repertório de conceitos elaborados nos séculos XIX e XX. A propósito, desafiam não apenas a atualidade, mas o seu modo de constituição: o antropocentrismo que se expressa no dualismo entre sujeito e objeto e na primazia do método. Um desses acontecimentos desafiadores está na passagem da primeira metade do século XX: a decadência do europeísmo e a ascensão do americanismo. Nesse momento, surge, na expressão de Gramsci (2001), um novo homem - pragmático, utilitário e violento: seu protótipo é o aventureiro e 
conquistador Robinson Crusoe (DEFOE, 2001) e sua expressão lapidada é o beligerante George W. Bush. Surge um novo estilo de vida: consumista, hedonista, presentista e conformista. O Trabalho é a referência ideológica da vida cotidiana. Seu protótipo é o lema de Franklin: "time is money" (WEBER, 1992). Na expressão de Marcuse (1999), o que acontece é a institucionalização da destruição da Natureza no contexto da destrutibilidade geral: é o predomínio nos indivíduos de uma estrutura de caráter destrutiva. Sennett (2001), duas décadas depois de Marcuse, não pouparia nem o caráter individual: ele mesmo objeto de uma corrosão, fruto da crescente exigência de adaptação e da lógica da substitubilidade.

Mas a euforia com os anos dourados do pós-guerra não gerou uma condição duradoura para o sistema produtor de mercadorias. Por isso, um marco mais específico dos tais acontecimentos contemporâneos pode ser o final dos anos 1960. São os sintomas de saturação da longa onda de expansão do Capital (MANDEL, 1985) e os primeiros indicadores de esgotamento das fontes naturais. O Capital, que antes superara a resistência dos trabalhadores, agora se depara com outros obstáculos. O primeiro é a sua própria eficácia e suas fantásticas forças produtivas (destrutivas): a oferta cresce e surge uma nova concorrência. Desde então, há um frenesi de reestruturações, quase todas focalizadas na redução de custos: enxugamento das estruturas, terceirização ou megafusões. O Capital esbarra em suas próprias barreiras. Outro obstáculo é o esgotamento dos recursos naturais. Em ambos os casos, a composição orgânica do Capital é alterada e a taxa de lucro declina: em seu apogeu, o mercado se revela inviável. Assim, a vida aparece como o avesso do projeto antropocêntrico: da dominação do mundo ao mundo em descontrole (GIDDENS, 2000). Há contradições evidentes: abundância e fome, esclarecimento e estupidez, coragem e medo. A violência que resulta em mortandade é crescente: na guerra, no tráfico ou no tráfego. São acontecimentos sociais, políticos, econômicos, culturais e ecológicos que não podem mais ser entendidos separadamente. Há algo em comum entre a apatia política e a violência social. É por serem inextricáveis que esses acontecimentos podem ser reveladores do esgotamento de um modus vivendi fundado nas relações de dominação e de exploração: dos homens com a Natureza e dos homens entre si. Isso atualiza a angústia crítica da década de 1940: “... a 
humanidade, em vez de entrar num estado verdadeiramente humano, está se afundando numa nova espécie de barbárie" (HORKHEIMER; ADORNO, 1985, prefácio). Há um mal-estar geral entre os que estão inseridos na produção destrutiva e na destruição criativa: os sintomas são diversos.

Ao mesmo tempo, há pressa no abandono de conquistas do pensamento e impaciência na formulação de novos argumentos. Isso já teria sido apontado por Horkheimer e Adorno (1985) como um obstáculo ao progresso do saber. É uma impaciência oriunda da timidez no contradizer e do agir por interesse: se expressa no fetichismo verbal. Em boa parte, parece prevalecer a lógica da descartabilidade ou da destrutibilidade: no mercado e na ciência. É assim que importantes idéias se perdem, dando lugar a versões bem mais simplificadas e palatáveis a um mercado editorial que clama cada vez mais por mensagens positivas e ligeiras. Contos de fadas: essa é a expressão utilizada por Harvey para referir-se à "crença dominante" no debate contemporâneo "de que um dia houve estruturalismo, modernismo, industrialismo, marxismo, e de que se tem agora pós-estruturalismo, pós-modernismo, pós-industrialismo, pósmarxismo, pós-colonialismo e assim por diante" (HARVEY, 2004, p. 25).

$O$ pensamento aqui arriscado tem como referência que as configurações sociais hodiernas são muito diferentes daquelas do século XIX e de grande parte do XX. Há acontecimentos que escapam aos clássicos do pensamento moderno. $\mathrm{O}$ mundo atual apresenta-se como uma combinação contraditória de progressos, estagnações e regressões. No mundo efêmero de Berman (1986), há permanências anacrônicas. A vida continua cada vez mais um apêndice da maquinaria produtiva submetida à lógica do lucro. Para Lefebvre (1991), trata-se do cotidiano apropriado pelo Capital. Para Adorno (1993), nada escapa à lógica do lucro: a amizade, o casamento ou a religião. Trata-se da vida danificada, prejudicada, vida exteriorizada. Nela, meios e fins são invertidos ou a essência do homem é invertida: a essência torna-se o trabalho, esse produto do Capital, que adquire um fim em si mesmo. A atividade é que se torna decisiva para a vida humana e não os seus resultados: os produtos e as obras. Produzir torna-se mais importante que usufruir as conquistas do trabalho. A vida torna-se para o trabalho e pelo trabalho e não para além do trabalho: tendo 
suas conquistas como pressuposto. Isso significa, de fato, vida voltada para o Capital.

Outro pensamento arriscado é que a Natureza é uma idéia-chave para a compreensão da cena contemporânea. A Natureza é um conceito paradoxal: na proporção de sua importância, foi esquecida, mal entendida, renegada, secundarizada. Ou seja, um conceito prejudicado. Nenhuma das parcelas da ciência (essa parcela do saber) conseguiu entendê-lo. É impossível ao saber disciplinar entender a Natureza (e o Homem). Essa impossibilidade deve-se ao fato de que a Natureza e o Homem não são objetos propriamente, justamente o que fazem as ciências parcelares: a objetualização da Natureza e do Homem. Simplificar para conhecer ou desqualificar para dominar. O resultado é conhecido: simplifica, mas não conhece; desqualifica, mas não domina. "Apenas presumimos dominar a Natureza” (HORKHEIMER; ADORNO, 1985, p. 19).

Por outro lado, não há que se abandonar certos progressos do pensamento social: suas ausências ofuscam fenômenos já desvendados. Talvez seja mais prudente revisitá-los, reinterpretá-los, desembaçá-los e livrá-los de deformações agregadas por usos apressados e pragmáticos no século mais destrutivo da história. Isso evita o desperdício e o descarte. Karl Marx é um desses autores que têm sido impacientemente descartados. Há como entender essa atitude e até mesmo esse antimarxismo. Em boa parte, ele é uma reação aos marxismos do século XX e sua pressa em produzir outro mundo. Mas parece que há uma cratera entre Marx e o militantismo marxista do século XX. O ambientalismo parece ser uma dessas arenas contemporâneas onde Marx tem sido descartado ${ }^{3}$. Bihr (1998) afirma tratar-se até mesmo de uma resistência ao proletariado e seus sindicatos e partidos. Isso seria uma herança da hegemonia socialdemocrata no movimento operário nos anos dourados do capitalismo. Nessas condições, o operariado se mostrou solidário à lógica produtivista (destrutivista). Nascido num contexto de bipolarização entre o bloco capitalista e o bloco socialista e fortemente motivado pelas ameaças de

3 Vale enfatizar que esse descarte de Marx e do marxismo não é universal no ambientalismo, nem de modo latente, nem de modo explícito. Há diversos ambientalismos que lidam com práticas e discursos que enfatizam a necessidade de mudanças que apontem para a formação de outra sociedade, diferente do capitalismo. 
uma guerra nuclear, o ambientalismo e depois a Educação Ambiental trazem, em si, um componente pós-modernista e, por isso, antiindustrial, antiurbano e antimarxista. Exemplar desse antimarxismo é um texto do músico e ecologista Gilberto Gil. Nele, o autor reclama da insensibilidade para com a crítica ambiental tanto no ambiente político quanto no ambiente intelectual brasileiro. Gil (2003, p. 50) afirma que esse esquecimento da Natureza é uma "conseqüência da poderosa (e pensada) influência que o pensamento sociológico europeu - especialmente em sua vertente marxista - exerceu em nossos meios mais letrados, de artistas a professores universitários, passando por escritores e jornalistas".

\section{A Natureza e o Homem: identidade e alteridade}

Desde os primeiros tempos, no Ocidente, Natureza e Homem foram pensados dentro de uma perspectiva de identidade ou de dicotomia: ora o Homem é um ser subsumido na Natureza, ora a Natureza é aquilo que deve ser dominado pelo Homem. Essas perspectivas que oscilam da identidade à dicotomia entre a Natureza e o Homem contêm em si o mesmo limite: ambas não conseguem entender a relação entre os entes, porque sequer compreendem a idéia de relação. Relação é o que pressupõe a diferença e o reconhecimento da alteridade: identificados ou dicotomizados, Natureza e Homem não se relacionam. O pensamento teve que esperar que a dialética se tornasse materialista para que emergisse um conceito de Natureza no qual o Homem está inserido: sem se submeter a ela, sem se diferenciar dela, mas diferenciando-se nela. Isso significa que o Homem é um ser que constrói sua própria existência na Natureza, o que é uma manifestação da anterioridade da Natureza e, mais uma vez, de sua alteridade. Adorno capta essa dialética de Marx. Nela, a Natureza é o ponto de partida e a História é uma forma de conduta que "se caracteriza antes de tudo pelo fato de aparecer nela o qualitativamente novo..." (ADORNO, [19--], p. 1). Se até Marx o conceito de Natureza aparecera associado ao conceito de dominação, a partir dele a Natureza aparece conciliada com o Homem. Ela é o corpo inorgânico do homem: "O homem vive da natureza, ou também, a natureza é o seu corpo, com o qual tem de manterse em permanente intercâmbio para não morrer" (MARX, 2001, p. 116). 
Em Marx, não apenas a relação do Homem com a Natureza, mas as relações entre o indivíduo humano, a sociedade e a Natureza são entendidas a partir da idéia de História Natural: “A sociedade é (...) a plena unidade essencial do homem com a natureza, a verdadeira ressurreição da natureza, o naturalismo acabado do homem e o humanismo acabado da natureza" (MARX, 1987, p. 175). Nessa passagem dos "Manuscritos", Marx refere-se à "associação dos indivíduos livres": "a verdadeira solução do antagonismo entre o homem e a natureza, entre o homem e o homem, a resolução definitiva do conflito entre existência e essência, entre objetivação e auto-afirmação, entre liberdade e necessidade, entre indivíduo e gênero" (MARX, 1987, p. 174).

$\mathrm{Na}$ dialética materialista, referência para o entendimento do Homem na Natureza é o Trabalho. O Trabalho é uma atividade na qual se relacionam homens e Natureza e, nessa relação, o Homem participa na condição de "um ser corpóreo, dotado de forças naturais" (MARX, 1987, p. 206). O processo de trabalho seria, assim, constituído de três momentos determinados pela Natureza: a atividade transformadora, a matéria transformada e os meios dessa transformação. É Marx que afirma: "O homem é imediatamente ser natural. Como ser natural vivo, está, em parte, dotado de forças naturais, de forças vitais, é um ser natural ativo" (MARX, 1987, p. 206). No processo de trabalho, a atividade é o que mobiliza forças naturais: os braços, as pernas, a cabeça e as mãos, "que o trabalhador põe em movimento, a fim de 'apropriar-se da matéria natural na forma utilizável para sua própria vida” (MARX apud DUARTE, 1993, p. 48). O mesmo ocorre com a matéria sobre a qual se trabalha: "O trabalhador nada pode criar sem a natureza, sem o mundo externo sensível" (MARX, 2001, p. 112). Idêntica é a condição dos instrumentos de trabalho: as ferramentas simples, depois as ferramentas complexas, a maquinaria e depois a diversidade de recursos energéticos para mover as máquinas, tudo feito com materiais da Natureza: "A tecnologia é denominada, em 'O Capital', a revelação da relação ativa entre o homem e a natureza" (DUARTE, 1993, p. 51). Trabalho é o encontro da Natureza com a própria Natureza: da natureza interna a cada homem singular com a natureza externa comum a todos. Ao trabalhar, o Homem transforma a Natureza em produtos que satisfazem as necessidades da vida: 
necessidades do "estômago ou da fantasia". Ao trabalhar, o Homem cria a propriedade privada, cuja origem é a Natureza. Sobre isso, Marx escreveu: "O homem, ao produzir, só pode atuar como a natureza, isto é, mudando as formas da matéria. (...) O trabalho não é, por conseguinte, a única fonte dos valores de uso que produz, da riqueza material. (...) o trabalho é o pai, mas a mãe é a terra" (MARX, 1982, p. 50). Essa idéia aparece também no conceito de produto, o resultado do trabalho: "O produto é um valor-deuso, um material da natureza adaptado às necessidades humanas através da mudança de forma" (MARX, 1982, p. 205).

$\mathrm{Na}$ dialética materialista, a idéia de história natural não é entendida como a "história da natureza à maneira como a natureza é objeto das ciências da natureza", da mesma forma como a Natureza "não tem absolutamente nada a ver com o conceito de natureza das ciências naturais matemáticas" (ADORNO, [19--], p. 1). A meta da História Natural é "suprimir a antítese habitual entre natureza e história; (...) levar tais conceitos até um ponto em que a mera separação entre eles seja superada" (ADORNO, [19--], p. 1). A História Natural não se apresenta, pois, como uma síntese metodológica entre "naturalistas e históricos". É mudança de perspectiva que supõe que o Homem "deve ser compreendido apenas como cruzamento do ser histórico e do ser natural" (ADORNO, [19--], p. 9). Assim é, portanto, o Homem: natural-histórico. $\mathrm{Na}$ dialética materialista, a origem da diferença do Humano está no trabalho, esta forma qualitativamente diferente de se relacionar com a Natureza: uma relação com base numa atividade movida não apenas por uma causalidade - a necessidade - mas também por uma finalidade - a liberdade. Um momento particular da relação entre genericidade humana e objetivação aparece na diferença entre a "atividade vital" do Homem e a dos animais. A diferença mais importante é a lucidez presente na atividade vital humana e isso se define pelo télos da atividade: "A atividade vital lúcida diferencia o homem da atividade vital dos animais" (MARX, 2001, p. 116). A diferença entre o Homem e o animal não é a produção de coisas úteis, já que o animal "também produz": "ergue um ninho, uma habitação, como as abelhas, os castores, as formigas, etc." (MARX, 1987, p. 117). Os animais produzem movidos pela "necessidade física imediata", mas o Homem, ser lúcido, produz a sua própria vida. Não há trabalho sem télos e o homem 
começou a produzir ferramentas porque, num certo sentido, já havia conquistado alguma liberdade: aquela liberdade inferior. Liberdade em relação ao tempo necessário à manutenção da sobrevivência, um tempo de vida condicionado pelo domínio da necessidade e pelas penúrias da vida. É essa conquista que permite ao homem começar a criar coisas produtoras de coisas: visando à liberdade superior, o homem começou a criar ferramentas de trabalho. Eis o primeiro produto do trabalho propriamente: as ferramentas ou a especialização da mão: “(...) a ferramenta significa a tarefa especificamente humana, a reação transformadora do homem sobre a natureza" (ENGELS, 1991, p. 25).

Mas, em que sentido tais conquistas fornecem ao homem novos meios de emancipação? É que as ferramentas de trabalho - mesmo as mais simples - criam condições para que o homem não precise sacrificar seu corpo e sua alma para manter-se vivo. Eis o télos do trabalho: liberar o homem do sacrifício do trabalho, abolir da vida a fadiga, dar por cumprido o castigo divino e permitir o retorno dessacralizado ao paraíso bíblico, o que significa superar o reino da necessidade e conquistar aquela liberdade superior, a do desenvolvimento das potencialidades humanas. No sentido religioso esse "além" é além da vida nesse mundo, o mundo dos homens. $\mathrm{Na}$ dialética materialista, esse "além" é superação, é a conquista da liberdade. Para compreender essa teleologia, é expressiva a diferença que Marx faz entre fato histórico e ato histórico. A satisfação das primeiras necessidades - a produção da vida material - caracteriza a conquista de um grau de liberdade. A conquista dessa liberdade inferior é fato histórico, mas não é ato histórico. O trabalho como ato histórico é o que só pode ser pensado com a produção de ferramentas, pois, "uma vez satisfeita a primeira necessidade, a ação de satisfazê-la e o instrumento já adquirido com essa satisfação levam a novas necessidades - e essa produção de novas necessidades é o primeiro ato histórico" (MARX; ENGELS, 2001, p. 10). Até então, esse ser diluído na Natureza não era propriamente Homem. Este somente afirma sua existência em seus atos históricos. 


\section{Dominação, recalcamento e revolta da Natureza}

Desde o princípio, a relação entre o Homem e a Natureza tem sido de dominação. Mas a dominação não é inata, não é herança da Natureza: foi viabilizada historicamente mediante o confronto de indivíduos reais com a Natureza e com as condições concretas da existência. É dominação reativa, que resulta do espanto ou do medo que o Homem sentiu ao alienar-se na Natureza, ao começar a constituir seu eu, a perceber o outro com o qual ele se relaciona. No animismo, o que o Homem sente como "algo de sobrenatural não é nenhuma substância material, mas o emaranhado da natureza em face do elemento individual" (HORKHEIMER; ADORNO, 1985, p. 29). É daí que surge o medo e, dele, dominação e violência. Isso tem seus desdobramentos: se o medo vem do desconhecido, dele "o homem presume estar livre quando não há nada mais de desconhecido". É por isso que desencantar o mundo é destruir o animismo.

A relação de dominação que o Homem estabelece com a Natureza caracteriza o protótipo da relação, também de dominação, que os homens estabelecem entre si. Superada a vida nômade e a comunidade primitiva, a fixação da propriedade privada marcaria a transposição dessa dominação para as relações entre os homens. $\mathrm{O}$ trabalho era o meio de se apropriar da Natureza, mas, com a sedentarização da vida, "a ordem social foi instaurada sobre a base da propriedade fixa. Dominação e trabalho separaram-se" (HORKHEIMER; ADORNO, 1985, p. 28).

Para se constituir, o Homem teve de ousar dominar a Natureza e era preciso conhecê-la. Cedo o Homem percebeu que sua superioridade está no saber, o que marcou, desde então, o caráter utilitário do conhecimento: conhecer para dominar. A dominação é um traço que o Homem traz das penúrias da vida primitiva. É desde lá que se processa a formação humana. É desde lá que a práxis fracassa. E, desde então, não houve progresso: até hoje acompanha a práxis o momento de não-liberdade que ela arrastou consigo, ou seja, "agir contra o princípio do prazer a fim de preservar a própria existência" (ADORNO, 1995, p. 206). O fracasso da práxis é a alienação. O sintoma é evidente: “(...) momento da consumação, a razão tornou-se irracional e embrutecida" (HORKHEIMER, 2000, p. 131). Isso permite 
afirmar que "o ataque totalitário da espécie humana em relação a tudo que se exclui dela mesma deriva mais das relações inter-humanas do que de qualidades inatas do homem" (HORKHEIMER, 2000, p. 112). Por outro lado, o utilitarismo já é expressão da objetualização da Natureza e da negação de seu valor-em-si: "O que os homens querem aprender com a natureza é como empregá-la para dominar completamente a ela e aos homens" (HORKHEIMER; ADORNO, 1985, p. 20). A relação entre poder e conhecimento não é simbiose moderna: seu protótipo já está nas relações primitivas. No capitalismo, o que ocorre é a radicalização do utilitarismo, que se expressa no problema da verdade: “o que importa (...) é (...) a 'operation', o procedimento eficaz” (HORKHEIMER; ADORNO, 1985, p. 19). Isso bloqueia a experiência. O esclarecimento, que visava à emancipação, torna-se dominação. Impregnado de dominação e objetualizando todo o seu entorno, "pôs de lado a exigência (...) de pensar o pensamento. (...) O procedimento matemático tornou-se (...) o ritual do pensamento" (HORKHEIMER; ADORNO, 1985, p. 37). Isso compromete a autonomia do pensamento, já que: "A técnica é a essência desse saber, que não visa (...) o prazer do discernimento, mas (...) a utilização do trabalho de outros, o capital" (HORKHEIMER; ADORNO, 1985, p. 20).

É com base nisso que os frankfurtianos pensam a relação entre mito e esclarecimento. O mito já era esclarecimento, uma vez que ele foi tentativa de ordenar o desconhecido para dominá-lo: "O mito queria relatar, dominar, dizer a origem, mas também expor, fixar, explicar. (...) Muito cedo deixaram de ser um relato, para se tornarem uma doutrina" (HORKHEIMER; ADORNO, 1985, p. 23). Mas o esclarecimento que desencanta o mundo não supera o mito: “(...) o esclarecimento fica cada vez mais enredado, a cada passo que dá, na mitologia” (HORKHEIMER; ADORNO, 1985, p. 26). A recaída do esclarecimento no mito que ele visava a superar tem suas conseqüências. Uma delas é a relação do Homem com a Natureza e com o medo do qual o esclarecimento prometia livrá-lo. Hoje, "a terra (...) esclarecida resplandece sob o signo de uma calamidade triunfal” (HORKHEIMER; ADORNO, 1985, p. 19). O utilitarismo bloqueia o entendimento entre os homens e a Natureza. A conseqüência é inevitável: "(...) de fato, estamos submetidos à sua necessidade" (HORKHEIMER; ADORNO, 1985, p. 20). Isso proporciona outro 
entendimento da idéia de alienação em Marx: um entendimento que se situa além da divisão do trabalho. A alienação é referência importante para o (des)entendimento do Homem com a Natureza na sociedade regida pela lógica da produção e do consumo: essa circunstância histórica em que a "valorização do mundo das coisas" é simultânea a uma "desvalorização do mundo dos homens" (MARX, 2001). É por isso que alienação é alienação da Natureza: separação do Homem daquilo que lhe é o chão. Se na origem o Homem se aliena na Natureza para constituir-se, no capitalismo tardio a socialização radical condiciona todo indivíduo a alienar-se da Natureza para integrar-se à lógica da produção e do consumo. Isso define a alienação, que, agora, mais que o bloqueio do progresso, proporciona um retorno à barbárie.

Submetida à lógica do lucro, a apropriação privada da Natureza e a sua redução à condição de matéria-prima equivalem à apropriação do Homem e sua rendição à condição de trabalhador. "O trabalho se torna vítima de um poder que ele mesmo criou” (MARCUSE, 1978, p. 255). O momento da objetivação torna-se somente exteriorização. Isso remete ao conceito de carecimento humano. No momento da exteriorização, o homem é posto sob determinação da propriedade privada e, assim, o carecimento torna-se egoísta: mero ter. Ao objetivar-se, o Homem cria produtos, mas, quando os produtos tornam-se mercadorias, a objetivação torna-se exteriorização. Nesse ambiente, cada nova mercadoria "é uma nova potência do engano recíproco e da pilhagem recíproca” (Marx, 1987, p. 182). A vida alienada e danificada aparece para Marx como o resultado do condicionamento do trabalho pela propriedade burguesa ou por aquilo que Adorno caracterizaria como coerção funcional: circunstância em que o indivíduo se vê condicionado por um descolamento entre o progresso da cultura e o progresso da liberdade e da felicidade. Para Marx (1987), o momento elevado desse poder sobre a vida do Homem é o dinheiro, a forma sublime da propriedade. O poder do dinheiro expressa o poder que o Homem não tem mais sobre sua própria vida: “(...) é a capacidade alienada da humanidade” (MARX, 1987, p. 196). Ter, no sentido egoísta de ter para si ou de ter de forma privada, torna-se mais importante do que ser, e o dinheiro, expressão da propriedade, torna-se um fim em si mesmo, torna-se o poder que substitui o poder que o Homem não mais tem sobre si. 
"Capitalismo tardio" é uma situação na qual "as relações de produção se revelam mais elásticas do que Marx imaginara", desenvolvendo, assim, mecanismos que permitem a permanência extemporânea da ideologia da produtividade. Num de seus últimos textos, Adorno (1995) fez a crítica da tese segundo a qual o mundo que se forma a partir dos anos 1960 se encontra de tal maneira determinado pela técnica que "a relação social que outrora definia o capitalismo, (...) a contradição de classes, perdeu a relevância” (ADORNO, 1994, p. 63). Segundo o frankfurtiano, fatos como a inexistência de uma consciência de classe nos países capitalistas dominantes ou o avolumamento do progresso técnico e o declínio da participação do trabalho vivo nas atividades industriais "só de um modo muito forçado e arbitrário são ainda interpretáveis sem utilizar o conceito-chave 'capitalismo'. A dominação sobre seres humanos continua a ser exercida através do processo econômico" (ADORNO, 1994, p. 67). Alienação é esse fenômeno que viabiliza a permanência do capitalismo, num contexto em que a sua irracionalidade - algo que se demonstra na desproporção, na superfluidade e no desperdício - e as suas contradições tornam-se expostas. Isso é o que define o capitalismo tardio ou a extemporaneidade do sistema produtor de mercadorias. A despeito de todo o progresso no domínio da técnica e do crescimento da produção, a atual sociedade revela aspectos estáticos. Eles fazem parte das relações de produção, nas quais não há progresso desde que o capitalismo existe. Relações de produção que "não são apenas as de propriedade, mas também as de administração, abrangendo até o papel do Estado como o capitalista total" (ADORNO, 1994, p. 69). O resultado desse triunfo da lógica da produção e do consumo é a aparência "de que o (...) o ideal seria a plena ocupação e não o interesse em libertar-se do trabalho heterônomo [sic]" (ADORNO, 1994, p. 69). Mas em que sentido essas relações de produção se estagnaram, a despeito de todo o progresso das forças produtivas? Essa questão remete ao descolamento entre o interesse objetivo e a espontaneidade subjetiva. É algo que seria decorrente de dois fatores. De um lado, a "organização da sociedade impede, de um modo automático ou planejado, pela indústria cultural e da consciência e pelos monopólios de opinião, o conhecimento e a experiência dos mais ameaçadores eventos" (ADORNO, 1994, p. 70). De outro lado, e "muito 
além disso", a socialização radical "paralisa a simples capacidade de imaginar concretamente o mundo de um modo diverso de como ele dominadoramente se apresenta àqueles pelos quais ele é construído" (ADORNO, 1994, p. 70).

Uma vida danificada é aquela que se define a partir de uma relação de sujeição ao processo produtivo, o que "impõe de maneira humilhante a cada um algo do isolamento e da solidão que somos tentados a considerar como objeto de nossa superior escolha" (ADORNO, 1993, p. 21). Na sociedade da produção e do consumo, as "ordenações práticas da vida, que se apresentam como se favorecessem ao homem, concorrem, na economia do lucro, para atrofiar o que é humano" (ADORNO, 1993, p. 34). O que danifica a vida é que meios e fins se vêem confundidos ou ela própria se reduz a meio de vida: seu télos torna-se o trabalho sem télos. Marcuse (1982) refere-se a essa vida tendo por base as necessidades falsas e verdadeiras. Falsas são aquelas superimpostas ao indivíduo por interesses econômicos particulares, as que perpetuam a labuta e a agressividade. Trata-se de uma vida falsa porque o que sucede com sua satisfação não é a felicidade, mas a euforia. A produção e o consumo reivindicam o indivíduo inteiro. $\mathrm{O}$ resultado disso é uma identificação imediata do indivíduo com a sociedade. (MARCUSE, 1982). Isso caracteriza uma pseudo-individuação: “O tempo livre continua a ser o reflexo de um ritmo de produção imposto de modo heterônomo [sic] ao sujeito, ritmo que é mantido forçosamente mesmo nas pausas cansadas" (ADORNO, 1993, p. 154).

Por essa via, a questão a ser pensada é a da relação entre objetivação e exteriorização ou entre o progresso das "coisas novas" postas pelo Homem e o tempo e energia de vida que essas mobilizam no esforço de adaptação. Essa é a dialética do esclarecimento: o progresso que emancipa o Homem na Natureza exige a autodominação visando à adaptação. Com exigências de adaptação cada vez maiores, a espontaneidade nos indivíduos "foi substituída por uma disposição de espírito que nos obriga a descartar-nos de qualquer emoção ou idéia que possa diminuir nossa atenção às exigências impessoais que nos assaltam" (HORKHEIMER, 2000, p. 103). É daí que vem o conceito darwinista de adaptação: quem não se adapta não sobrevive, quem se adapta bem tem maiores possibilidades de sucesso. É visando a adaptar-se à lógica da 
produção e do consumo que os indivíduos se sacrificam: "Adaptar-se significa fazer-se igual ao mundo de objetos tendo em vista a autopreservação" (HORKHEIMER, 2000, p. 118). O darwinismo é exemplo da "inversão dialética do princípio de dominação pela qual o homem se torna ele mesmo um instrumento da mesma natureza daquele que ele domina" (HORKHEIMER, 2000, p. 99), ou seja, é expressão da "identidade entre a dominação do homem sobre a natureza e sua submissão à mesma" (HORKHEIMER, 2000, p. 99). A transição do darwinismo biológico para o darwinismo social seria na substituição gradual da seleção natural pela ação racional ou da sobrevivência pelo sucesso: ambos dependem da capacidade de adaptação do indivíduo às pressões culturais.

No pensamento social pós-século XVI, a individuação é pensada como antítese da socialização. As referências são a liberdade, a autonomia e a historicidade. Mas na sociedade capitalista, a "história regida pela lógica da produção e do consumo é tão somente (...) um destino cego" (HORKHEIMER; ADORNO apud MATOS, 1995, p. 95). A sociedade torna-se unidimensional, sem oposição; sociedade total, que só se identifica consigo mesma, marcada pela socialização radical do indivíduo.

Mas, no entendimento da relação entre o indivíduo, a Natureza e a cultura, os frankfurtianos estabelecem uma relação mais direta com Freud, na qual se pensa sobre a idéia de coerção funcional ou de civilização repressiva - segundo Marcuse (1999), uma civilização mais repressiva. Ao buscar identificar as causas do "mal-estar na civilização", o psicanalista estabelece uma pergunta básica: o que os homens pedem da vida e o que desejam nela realizar? A resposta de Freud é que os homens esforçam-se para obter a felicidade; querem ser felizes e assim permanecer, e a busca da felicidade tem diferentes sentidos: "Por um lado, visa a ausência de sofrimento e de desprazer; por outro, a experiência de intensos sentimentos de prazer" (FREUD, 1997, p. 94). Mas é em função da busca do prazer - portanto, da meta positiva - que o indivíduo define o sentido da vida e se coloca em movimento. É nesse ponto que Freud repõe sua pergunta: por que é tão difícil para o homem ser feliz? A resposta a essa questão conduziu o psicanalista à identificação de fontes de sofrimento ou de obstáculos com os quais o indivíduo se depara para realizar o princípio 
do prazer: “(...) o poder superior da natureza, a fragilidade de nossos próprios corpos e a inadequação das regras que procuram ajustar os relacionamentos mútuos dos seres humanos na família, no Estado e na sociedade" (FREUD, 1997, p. 105). A primeira dessas fontes é a Natureza interna e se manifesta no próprio corpo do indivíduo, que é "condenado à decadência e à dissolução". A segunda fonte provém da Natureza externa, "que pode voltar-se contra nós com forças de destruição esmagadoras e impiedosas", e a terceira é proveniente da relação que o indivíduo estabelece com outros indivíduos na sociedade, sendo esse sofrimento o mais penoso de todos, pois "tendemos a encará-lo como uma espécie de acréscimo gratuito”. Nesse ponto, Freud tem uma idéia que o aproxima de Max Weber. Os homens modernos têm muito orgulho dos feitos da ciência e dos progressos da civilização, mas os próprios indivíduos "parecem ter observado que o poder recentemente adquirido sobre o espaço e o tempo, a subjugação da natureza, (...) não aumentou a quantidade de satisfação prazerosa que poderiam esperar da vida e não os tornou mais felizes" (FREUD, 1997, p. 107). É por força dessa terceira fonte de sofrimento que Freud assinala que a causa fundamental do malestar do indivíduo é a repressão da civilização e que seríamos muito mais felizes se a abandonássemos.

Mas toda renúncia do indivíduo ao princípio do prazer torna-se uma fonte dinâmica de consciência, e cada nova renúncia aumenta a severidade e a intolerância da própria consciência. Para os frankfurtianos, o que há de dialética na socialização radical é que ela gera "o potencial de sua própria destruição, não só na esfera objetiva mas também na subjetiva" (HORKHEIMER; ADORNO, 1973, p. 41). Se o diálogo com Marx leva os frankfurtianos a atribuírem primazia às contradições sociais, o diálogo com Freud suscita um outro aspecto: as contradições entre a coerção e a renúncia aos princípios do prazer e da felicidade. A socialização radical do indivíduo na totalidade funcional revela um processo oposto ao das "comunidades": o que acontecia de "fora para dentro" agora afeta o íntimo dos indivíduos. A racionalização progressiva promove uma "socialização interna", mas "faz-se acompanhar de uma regressão igualmente progressiva”: “(...) como as renúncias cada vez maiores não encontram uma saída equivalente nas compensações, (...) os instintos assim reprimidos 
não têm outro caminho a não ser a rebelião" (HORKHEIMER; ADORNO, 1973, p. 41). Mas, a despeito de ser dominante, a alienação não é universal. Face às contradições sociais, ela não consegue "subsumir, em absoluto, todos os homens".

É nesse momento que a idéia de revolta da Natureza pode ser posta. A rebelião da Natureza é o que resulta do esforço individual de adaptação. Adaptação é repressão da espontaneidade e, por isso, dominação. É daí que vem a idéia de Natureza coagida e recalcada. Por um lado, a ênfase na adaptação como recurso de sobrevivência ou sucesso forma um tipo de consciência favorável ao conformismo. Horkheimer (2000, p. 113) afirma que "todo ser humano experimenta o aspecto opressor da civilização desde o nascimento”. É assim que os pais aparecem na vida das crianças: uma figura sobrenatural. É assim também que a "criança sofre ao submeter-se a essa força. (...) Ela é forçada a resistir à pressão imediata dos seus impulsos, a diferenciar entre a si mesmo e o ambiente, a ser eficiente" (HORKHEIMER, 2000, p. 113). É então que a Natureza começa a ser reprimida e, ao mesmo tempo, preparada para mais repressão: "A criança não enxerga o motivo de todas essas exigências. Obedece temendo ser repreendido ou castigado, temendo perder o amor dos pais pelo qual anseia profundamente" (HORKHEIMER, 2000, p. 113). É também nesse momento que começa a formar-se esse potencial de revolta: “(...) o desprazer ligado à submissão permanece, e ela desenvolve uma profunda hostilidade para com o pai, que é posteriormente transformada num ressentimento com a própria civilização" (HORKHEIMER, 2000, p. 113). Dessa forma, a revolta da Natureza é a revolta dos indivíduos contra a civilização repressiva. É esse "ódio à civilização" que se manifesta na crescente intolerância e agressividade, no isolamento, na apatia, na depredação do patrimônio público, na gula, na insônia, na ansiedade ou em diferentes modos de adoecimento físico ou mental. Nada disso resulta de dificuldades pessoais no mundo. O indivíduo desenvolve esse potencial de revolta quando descobre "que as renúncias (...) que dele (...) se espera[m] não são adequadamente compensadas" (HORKHEIMER, 2000, p. 114). Essa Natureza reprimida ou essa revolta contida pode ter, no entanto, desdobramentos históricos paradoxais: ela pode assumir a forma de rebeliões sociais, de crime organizado e de 
transtorno mental, mas pode ser manipulada também como um meio de perpetuação das próprias condições que a provocaram e contra as quais se insurge. É assim que a "civilização como irracionalidade racionalizada integra a revolta da natureza como outro meio ou instrumento" (HORKHEIMER, 2000, p. 99).

\section{Considerações finais}

Parece que, após a contestação generalizada do final dos anos 1960, o Capital revelou-se mais elástico e se apropriou do ambientalismo por meio de um discurso que aos poucos penetra na opinião pública e por meio de inúmeras mercadorias destinadas a um mercado cada vez mais "exigente". Importantes nesse processo foram os guardiães internacionais do sistema produtor de mercadorias: a ONU e as instituições de Breton Woods. Isso ocorreu tanto pela mobilização de inúmeras conferências intergovernamentais quanto pela realização de pressões visando à assimilação do discurso pelos Estados Nacionais. A partir do momento em que a Educação Ambiental entrou na agenda oficial, uma série de manuais têm sido publicados com a finalidade de capacitar os agentes para ações educativas cuja meta são as mudanças comportamentais. Um desses manuais é oriundo da UNESCO - United Nations Environment Programme: "Conceitos para se fazer Educação Ambiental" (SÃO PAULO (Estado), 1997). Nas páginas iniciais desse texto oficial, há uma referência paradigmática à Educação Ambiental. Ela é "uma nova forma de encarar o papel do ser humano no mundo” (SÃO PAULO (Estado), apresentação). Sua tarefa histórica é inconfundível - "a educação ambiental é bastante subversiva" e visa a "soluções que alteram ou subvertem a ordem vigente" (SÃO PAULO (Estado), apresentação).

Entretanto, sob a aparência da subversão, há um expressivo esforço buscando criar condições para a permanência do sistema que coloca homens e Natureza em situação antagônica. Um exemplo são as coletas seletivas de lixo que focalizam a classificação e a reciclagem do lixo, mas se omitem quanto à produção do lixo: o consumismo, o desperdício, a superfluidade e a desproporção. Isso permite pensar num sentido deseducativo da Educação Ambiental que parece localizar-se nas 
mensagens carregadas de ideologia. Ele se expressa, por exemplo, na medida em que tais mensagens, no desespero (justificado ou não) de salvar a Natureza, sinalizam ora para uma identificação, ora para uma separação entre Natureza e Cultura. Sua concepção hipostasiada da Natureza e do Homem condiciona o negligenciamento da crítica ao capitalismo e a impede de caracterizar-se como uma recusa à alienação mercantil, que objetualiza a Natureza e o Homem, reduzindo este à condição de trabalhador e de consumidor e aquela à condição de matéria-prima. Assim, o cenário para o qual sinaliza é mais condizente com a manutenção do que com a superação da sociedade regida pela lógica da produção e do consumo visando ao lucro.

O desperdício do potencial subversivo da Educação Ambiental ocorre na medida em que tais mensagens não explicitam a relação entre o Homem e a Natureza, nem a condição do homem como ser naturalhistórico e a especificidade dessa relação na civilização burguesa. Desse modo, o potencial anticapitalista da educação ambiental é diminuído, eliminado ou mesmo invertido, já que suas mensagens veiculam a linguagem da dominação. Isso se explicita no modo latente ou manifesto como tais mensagens caracterizam a Natureza e o Homem, bem como a relação entre o natural e o cultural. Nessas definições, a Natureza é tida como o meio ambiente, o habitat, a casa do homem. Assim, o Homem, ele próprio, não é um ser natural. $O$ habitante não é Natureza: ele é um ser descolado da Natureza. Ao apresentarem dessa forma a Natureza e o Homem, esses materiais não contribuem para o entendimento do que esses entes efetivamente são; não compreendem o homem como ser naturalhistórico, desqualificam e objetualizam a Natureza.

Mas, afinal, o que seria uma EA subversiva no século XXI? As formulações de Adorno (1996) sobre a semicultura fornecem pistas para essa reflexão. A questão não é apenas de ordem metodológica, mas teleológica. Para ser subversiva, a EA tem que atuar na ruptura com o círculo da adaptação, fomentar condições para que o indivíduo reificado recupere a sua capacidade de refletir sobre as condições de sua reificação: formação pela via da auto-reflexão. Esta é a tarefa: “(...) a única possibilidade que resta (...) é a auto-reflexão crítica sobre a semiformação" (ADORNO, 1996, p. 410). No caso do indivíduo, auto-reflexão significa 
reflexão sobre sua condição social. A auto-reflexão, a reflexão sobre as condições em que ocorre a indiferença entre homens e coisas e homens e homens, é o que se coloca para a Educação como forma de evitar que a "revolta contida" ou a "natureza reprimida" seja manipulada pelas próprias condições que a provocaram. Ademais, a reflexão sobre o estado de contradição em que estão postos a Natureza, a Sociedade e o Indivíduo Humano é o que cria condições para a resistência ao não-conformismo, de forma a manter acesa a chama da superação histórica. Ademais, "o único meio de auxiliar a natureza é libertar o seu pretenso opositor, o pensamento independente" (HORKHEIMER, 2000, p. 129-130). Já que a alienação é, antes de tudo, auto-alienação, é pela razão e não por sua negação que se pode manter acesa a possibilidade de uma conciliação com a Natureza: "Sem combater a falácia de igualar natureza e razão, a humanidade deve tentar conciliá-las" (HORKHEIMER, 2000, p.127-128).

\section{Referências}

ADORNO, Theodor W. Mínima Morália: reflexões a partir da vida danificada. Tradução de Luiz Eduardo Bicca. São Paulo: Ática, 1993.

Capitalismo tardio ou sociedade industrial? In: COHN, Gabriel (Org.). Theodor Adorno. Tradução de Flávio R. Kothe, Aldo Onesti e Amélia Kohn. 2. ed. São Paulo: Ática, 1994. (Coleção Grandes Cientistas Sociais, n. 54). A Idéia de História Natural. Tradução de Bruno Pucci. São Paulo: Unimep, [19--].

Petrópolis: Vozes, 1995.

Palavras e Sinais: modelos críticos 2. Tradução de Maria Helena Ruschel. Teoria da semicultura. In: Educaşão \& Sociedade, Campinas, ano XVII, n. 56, p. 388-411, dez. 1996.

BERMAN, Marshall. Tudo que é sólido desmancha no ar: a aventura da modernidade. Tradução de Carlos Felipe Moisés e Ana Maria L. Ioriate. São Paulo: Companhia das Letras, 1986.

BHABHA, Homi. O local da cultura. Tradução de Myrian Ávila, Eliana Lourenço de Lima Reis e Gláucia Renate Gonçalves. Belo Horizonte: UFMG, 2001.

BIHR, Alain. Da grande noite à alternativa: o movimento operário europeu em crise. Tradução de Wanda Caldeira Brant. São Paulo: Boitempo, 1998.

DEFOE, Daniel. Robinson Cruqoé. Tradução de Pietro Nassetti. São Paulo: Martin Claret, 2001. 
DUARTE, Rodrigo A. de Paiva. Mimeses e Racionalidade: a concepção de domínio da natureza em Theodor W. Adorno. São Paulo: Loyola, 1993.

FREUD, Sigmund. O mal-estar na civilização. Tradução de Jayme Salomão. São Paulo: Imago, 1997.

ENGELS, Friedrich. Anti-Dühring: filosofia, economia política, socialismo. Rio de Janeiro: Paz e Terra, 1979. A dialética da natureza. São Paulo: Paz e Terra, 1991.

FOSTER, John B. A ecologia de Marx: materialismo e natureza. Tradução de Maria Teresa Machado. Rio de Janeiro: Civilização Brasileira, 2005.

GIDDENS, Anthony. O mundo em descontrole: o que a globalização está fazendo de nós. Tradução de Maria Luiza X. de A. Borges. Rio de Janeiro: Record, 2000.

GIL, Gilberto. Algumas notas sobre cultura e ambiente. In: TRIGUEIRO, André. Meio Ambiente no século XXI: 21 especialistas falam sobre a questão ambiental nas suas áreas de conhecimento. Rio de Janeiro: Sextante, 2003.

GRAMSCI, Antonio. Cadernos do cárcere. Tradução de Carlos Nelson Coutinho. Rio de Janeiro: Civilização Brasileira, 2001. v. 4.

HARVEY, David. Espaços de Esperança. Tradução de Adail Ubirajara Sobral e Maria Stela Gonçalves. São Paulo: Loyola, 2004.

HOBSBAWM, Eric. Era dos extremos: o breve século XXI: 1914-1991. Tradução de Marcos Santarrita. São Paulo: Companhia das Letras, 1995.

HEGEL, Georg Wilhelm F. Fenomenologia do Espirito. Tradução de Paulo Meneses. Petrópolis: Vozes, 1999.

HORKHEIMER, Max. Eclipse da Raz̃ão. São Paulo: Centauro, 2000.

HORKHEIMER, Max; ADORNO, Theodor. (Org.). Temas Básicos da Sociologia. Tradução de Álvaro Cabral. São Paulo: Cultrix, 1973.

. Teoria tradicional e teoria crítica. São Paulo: Abril Cultural, 1980.

- Dialética do esclarecimento: fragmentos filosóficos. Tradução de Guido Antonio de Almeida. Rio de Janeiro: Jorge Zahar, 1985.

HOMERO. Odisséia. Tradução de Carlos Alberto Nunes. Rio de Janeiro: Ediouro, 2001.

JAMESON, Frederic. Notas sobre globalização como questão filosófica. In: PRADO, José Luiz Aldair; SOVIK, Liv. Lugar global e lugar nenbum: ensaios sobre democracia e globalização. Tradução de Hélio de Melo Filho. São Paulo: Hacker, 2001.

LEFEBVRE, Henri. A vida cotidiana no mundo moderno. Tradução de Alcides João de Barros. São Paulo: Ática, 1991. A cidade do capital. Rio de Janeiro: DP\&A, 2001.

MANDEL, Ernest. O capitalismo tardio. Tradução de Carlos E. S. Matos, Regis de C. Andrade e Dinah de A. Azevedo. São Paulo: Nova Cultura, 1985.

MARCUSE, Herbert. Razãa e Revolução: Hegel e o advento da teoria social. Tradução de Marília Barroso. 4. edição. Rio de Janeiro: Paz e Terra. 1978. 
. Idéias sobre uma teoria crítica da sociedade. Tradução de Fausto Guimarães. 2. ed. Rio de Janeiro: Zahar, 1981.

- A ideologia da sociedade industrial. Tradução de Giasone Rebuá. 6. edição. Rio de Janeiro: Zahar. 1982.

. Eros e Civilização. Tradução de Álvaro Cabral. Rio de Janeiro: LTC, 1999.

. Herbert Marcuse (Entrevista). In: LOUREIRO, Isabel (Org.). Herbert Marcuse: A grande recusa hoje. Tradução de Isabel Loureiro e Robespierre de Oliveira. Petrópolis: Vozes, 1999.

MARX, Karl. Diferencia de la filosofia de la natureza en Demócrito y en Epicuro. Madrid: Ayuso, 1971.

O capital; Crítica da economia política. Tradução de Reginaldo Sant'Anna. 7. edição. São Paulo: Difel, 1982.

. Manuscritos econômico-filosóficos. Lisboa: Edições 70, 1987.

2001.

. Manuscritos econômico-filosóficos. Tradução de Alex Marins. São Paulo: Martin Claret,

MARX, Karl; ENGELS, Friedrich. A Ideologia Alemã. Tradução de Luiz Cláudio de Castro e Costa. São Paulo: Martins Fontes, 2001.

MATOS, Olgária C. F. Matos. A Escola de Frankfurt: luzes e sombras do Iluminismo. São Paulo: Moderna, 1995.

SÃO PAULO (Estado). Secretaria do Meio Ambiente. Conceitos para se fazer Educação Ambiental. São Paulo: A secretaria, 1997.

SENNET, Richard. A corrosão do caráter. Tradução de Marcos Santarrita. Rio de Janeiro:

Record, 2001.

WEBER, Max. A ética protestante e o espirito do capitalismo. Tradução de M. Irene de Q. F. Szmrecsányi e Tomás J. M. K. Szmrecsányi. 7. edição. São Paulo: Pioneira, 1992.

Artigo: recebido em 23/07/2008 - aprovado em 08/12/2008 